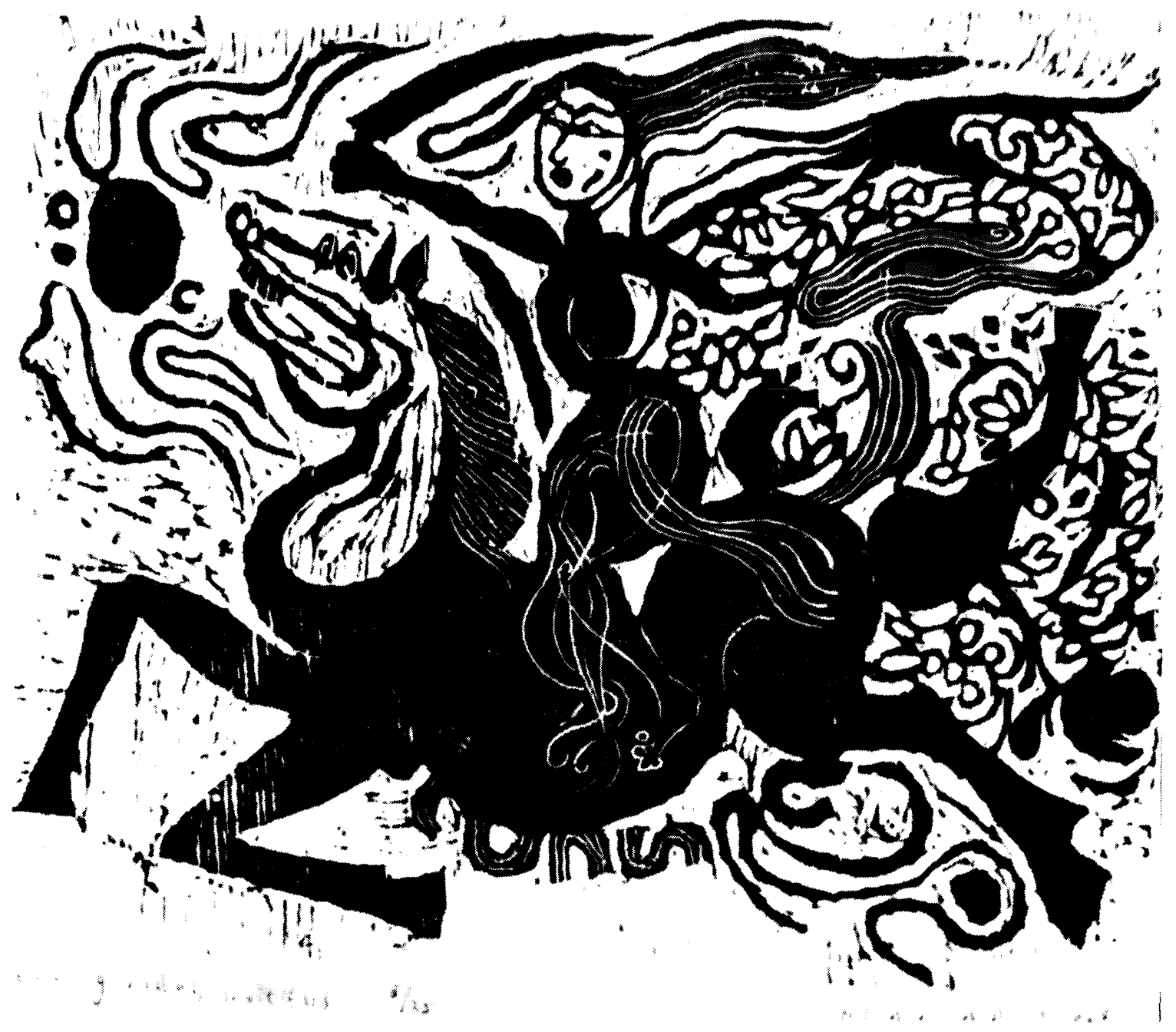

WAR UNLEASHED. A Plywood cut by Harjadi S., Bandung School of Fine Arts, 1968. 


\title{
WAR AND HUMANITY: NOTES ON PERSONAL EXPERIENCE*
}

\author{
Us amah \\ Translated by Helen Jarvis
}

\section{Editor's Note}

War is a strange element in the civilization of modern man. In this day and age, modern men, from the time they are small, are taught to cultivate love for their fellow human beings. And yet war has never been eliminated from history, including the history of modern men, for war seems to be a necessary evil.

In the face of war, where people kill one another, different men experience different feelings: some feel exalted, others feel afraid. And one such man is Usamah, a writer.

When the September Thirtieth Movement broke out, Usamah was one of those who actively defended his country against the Communists' efforts to gain control over it. Thus Usamah was involved in a type of war--people around him were killing one another. All this was only to be expected. It was also only to be expected that Usamah, a writer, could not bear to see it; and, in the same way, it was only to be expected that there would be others quite capable of bearing it. A writer, who must always train himself to use his finer feelings, always to see the human beings around him as unique realities, to try always to empathize with and understand the problems of other men, cannot stop himself from feeling compassion for others, even though they may be categorized politically as his most dangerous enemies. Mutual understanding will always bring those affected to a feeling of mutual compassion.

So, it is only proper that we recognize what is written below in Usamah's personal notes as the expression of the humanity that can never be eliminated from human existence, no matter how long nor how terrible the war that may befall them. This is the natural reaction of a man who sees others as his fellow men.

The Editors of Horison Djakarta, June 7, 1969

* This article originally appeared in the literary magazine Horison (Volume 4, number 8, August 1969). Horison is published in Djakarta; its editorial board is composed of Mochtar Lubis, H. B. Jassin, Zaini, Taufiq Ismail, Arief Budiman and Goenawan Mohamad. 
1.

It is certain that the former mayor of Solo, Utomo Ramelan, helped organize preparations for the Gestapu terror. Secretly, he moved his headquarters into the Baluwarti kraton. ${ }^{1}$ At that time, only a few people knew this for sure. Perhaps only eighteen people, who had been willing to stay awake nights and keep watch, really knew Utomo Ramelan's movements and where he was organizing his forces.

Exactly two days after the coup by the Revolutionary Council, ${ }^{2}$ the Pemuda Rakjat [Communist youth organization] emerged from their strongholds in Semanggi, Kampong Sewu and Medjo and milled about in great crowds in the streets of Pasar Kliwon, Gading and even up to the far end of Purwosari. They acted like victorious soldiers. From time to time they shouted: "Crush the Generals' Council." 3 Expressions of arrogance passed over their faces, perhaps because most of them were carrying weapons. (Only later did I find out that these guns were "Tjungs." 4 ) Protected by these guns, they launched a poster campaign.

On that day, our friends assigned to monitor the Djakarta radio broadcasts already could state positively that the PKI [Indonesian Communist Party] had had an important role in killing the Generals. Moreover, in closed discussions among likeminded friends, which were held immediately after we heard news of the coup, we concluded that the forebodings we had had for the last five years had come to pass. I was horrified by the reality we now faced.

However, we felt sure that the armed forces outside the city would focus attention on Solo because it was a PKI stronghold. And, indeed, five or six days after the abortive coup, there was talk that the Siliwangi ${ }^{5}$ were already among us. It was strengthened by the belief that they had been sent deliber-

1. Baluwarti kraton is the western section of the palace complex of the Susuhunan of Solo.

2. At the time of the coup, Revolutionary Councils were established by the conspirators both in Djakarta and in several regional centers.

3. The coup group claimed that it acted in order to prevent a Generals' Council from taking power; the same reason was given for the kidnapping and murder of the six army generals.

4. "Tjung" are a Chinese type of gun.

5. Siliwangi is the West Java Division of the National Army; in 1948, it supplied the core of the troops that suppressed the PKI after the Madiun Affair. 
ately because of their past experience. At first, I was inclined to believe this. But then our friends, as if spoiling for a fight, began a campaign, tearing down the inflammatory Pemuda Rakjat posters about the Generals and replacing them with new posters saying exactly the opposite; only then did we realize that the rumors were untrue. Several times brawls occurred without a single bullet being fired to break them up. At that time, there were still no military willing to "defend" us--in fact many of them were implicated. Emotion alone stirred our spirit and fired our courage. I must have made myself conspicuous enough to attract the attention of the PR, who immediately sent two "specials" to my home. Three times they came and left again; the thind time I met them myself. They asked me, "Where's Usamah?"; obviously they were not acquainted with me. I lied to them, saying that "Usamah" had gone to his parents' home in Pekalongan.

The "visits" from the two PR people made me feel unsafe at home. I began to suspect everyone around me. In the end I finally decided to "move" from my aunt's house and, at the same time, to leave the campus of Saraswati University. I decided to throw myself wholeheartedly into the campaign to "crush Gestapu."

After that, a series of things happened in quick succession. A clash with a group of PR under the protection of certain army elements from the motor pool, as I was on my way to the house of CPM Major Sdn.6 Impulsive, "emotional" wall scribblings (written just for revenge) implicating Sukarno and Subandrio, for which I got a tirade from Komresko Salopo. ${ }^{7}$ My detention for several days in the cells behind the East Pagelaran Police Station because I had said, "Sukarno, mastermind of Gestapu"-at that time, the "great man" was still "His Excellency, the Great Leader of the Revolution."

I worked to establish a network in the kampongs which were PKI strongholds. Several former members of the Anti-Communist Front who were attached to this network succeeded in gaining valuable information from the infiltration. When the RPKAD was seeking evidence that could be used as the basis for arrests, this network was extremely important. Perhaps the most complete reports to Intelligence came from these people.

6. Military Police Corps.

7. City police chief.

8. The RPKAD, the army para-commandos, were sent to Central Java, after the coup had been thwarted in Djakarta, in order to prevent the dissidents from establishing themselves there. 
2 .

About the beginning of November 1965, an Action Command to Crush Gestapu Interrogating Team was formed in Solo. I represented the Pasar Kliwon District Action Command. The city headquarters were in the town hall. At first, I was a typist, then an informant, then was promoted again to become an "inteliigence" assistant, with the specific task of verifying reports. Eventually, I was given charge over many problems.

There were unpleasant aspects for someone who knew a lot about local Communist affairs: Generally it was such people on the Team who were ordered to interrogate the prisoners. And I had reached this point without realizing that my position endangered my own life. It was most unpleasant. Of course it wasn't pleasant to talk to people whose eyes showed their hatred. Especially when they were people I knew personally. Twice I was forced to interrogate acquaintances. It happened like this.

3.

Ibu $Y$, a civics teacher in a Solo Senior High School, was related to a friend of mine. We had often met, the last time just a few days before september 30th. We were interested in similar things, so we often met to exchange views. I knew that she was an activist in the Non-Vak Sentral Teachers' Union, and from my friend (her relative), who did not like her at all, I was able to gain much information about her.

$Y$ was clearly taken aback at meeting me in the office of the Interrogating Team, and her mouth shut tight. Yet she must have been grumbling all the way down the corridor to my office, for I had overheard her scolding and threatening the guard outside. She had said she would not put up with such treatment and would report it to her elder brother, a colonel in Djakarta. She had continued, "I will not tolerate being suddenly detained like this for no reason whatsoever!"

"There are plenty of reasons, Y," I replied, rather sharply. She started, stared at me, her eyes opened wide, and then looked me up and down. I went on.

"And your brother is not a colonel. I know. So you needn't lie. He's Tjugito."

She was really stunned. Her eyes, which bulged like those of a fish, glazed over, and she no longer stared at me. My

9. A communist-dominated professional union.

10. Tjugito was a member of the Central Committee of the Communist Party. 
manner certainly must have seemed rough, though I hadn't intended it. I was sorry that she had spoken that way with the guard behind the office partition, since I was forced to utter the words which revealed who she really was. She fell silent. When I began the interrogation, her answers were short and to the point. Luckily, there wasn't much that she denied or contradicted, so the interrogation went smoothly. The one "accusation" which she did deny was that she had been present in the office of the City Committee of the PKI at the precise hour that the Radio Republic Indonesia announced the "thwarting of the Generals' Council." At first she lied, saying that during those hours she had been out of the city. When one of the guards slipped a pencil between her fingers and began bending her middle finger back over it, she began to confess that at the hour in question she was already back in solo, but not at the PKI office.

"Where were you?" I asked.

"I swear I was at home, dik Us,"11 she replied.

Her calling me "dik Us," which I was sure the others had heard, greatly endangered my position. At that time, everybody in Solo was full of suspicion. Everyone was suspect, including the people on the Interrogating Team. A few days before I examined Ibu $Y$, someone had had to be "taken into custody" because it was proved that he knew too many of the prisoners, and it came out that he had been using his position to help his friends.

I was very annoyed to hear Ibu Y call me "dik Us," although that was what she had usually called me. I had already warned her once that the "I" who sat behind the interrogation desk was not the "Usamah" she knew, but she took no notice of this warning. Some of the others in the room would certainly be suspicious. Because of fear perhaps, I felt compelled to order one of the special guards:

"Tonture this woman!"

To prevent Ibu Y from calling me "dik Us" anymore, I quickly left the room. Ibu $Y$ was then "sent to the operating room." The Commandant ordered me to continue the interrogation while she was being "worked over" in the "operating" room. When I entered, I almost couldn't believe it; she had been "worked over" so much that her skin was striped like a zebra's. She looked thinner than usual. Her ribs, poking out from under her breasts, looked like piano keys. She was thin all right.

11. "Dik Us," from adik Usamah, is a friendly form of address usually from an older to a younger person. 
It ended as it always does. Ibu $Y$ confessed. I was dubious when I heard her confession. I felt certain that she had not been able "to take it." Afterwards, she was put in with the other women prisoners in Camp II behind the town hall.

4.

My experiences in interrogating Doctor $X$ were quite different. As my aunt's family doctor, $X$ had taken care of her, as well as my cousins and myself, for many years. In fact, I was still supposed to return to his hospital for injections. He admonished me kindly, reminding me that, for the sake of my health, I still needed two or three more injections. He was the most genial doctor I had ever known. But this time he was brought before me as a leading figure in the HSI ${ }^{12}$ at the Baperki University, ${ }^{13}$ as a contributor to the PKI, as a member of the "Surakarta Revolutionary Council" and as a person who had once said that "the murder of the Generals was justified because they were too corrupt." But be that as it may, he was still $X$, the doctor $I$ knew. His friendly smile made it impossible for me to be formal with him. I was forced to be friendly too and offer him a "Menara" cigarette. He refused and even advised me not to smoke too much. I was really terribly sorry for him, after the interrogation, he would probably never be in a position to advise me again.

I had already gathered concrete and reliable facts about Doctor $x$. There was a recording of a telephone conversation between him and Utomo Ramelan. From this, I knew and am prepared to state positively that Utomo Ramelan planned the murder of local anti-Communist figures. There were photostats of memos and letters which he had written to Baperki/PKI people in Djakarta. A recording of his speech to the Civitas Academica of Baperki University. Photographs of his conferences with PKI leaders. It was quite complete; so that, properly speaking, I should only have had to put the evidence in front of him to have him sign it all immediately.

When the Team Commandant asked me to verify these facts once more, it was only because he hoped he might get some new leads.

Interrogating Doctor $X$ was not as easy as interrogating the people before him. What I got was not more information but rather an attitude which, if he persisted in it, would have made one sick. Doctor $X$ denied all the charges without giving

12. H.S.I., Himpunan Sardjana Indonesia, a communist-dominated association of university graduates.

13. Baperki was an organization mainly of Indonesian Chinese which was accused of having Communist affiliations. 
any explanations at all. I was very angry, but it was difficult for me to express this anger. The memory that he was our family doctor, the one from whom I usually sought help, the doctor who had succeeded in curing my aunt's chronic asthma, inhibited my desire not to be sentimental. This inner conflict was accompanied by feelings of irritation and rage. If only, yes, if only he had been someone else, he would have been "worked over" right at the start. I had already reached the point of wanting to take a stick to him myself.

It was hard to put on a show with Doctor $X$ as $I$ had with Ibu $Y$. And so I made up an excuse and suggested to my superior that he appoint another "expert," if possible someone with a scientific background, to work on Doctor $X$. The term "work on" was misunderstood. It wasn't another interrogator that was sent to question Doctor $X$ in my place but an "expert" in "working over." I was not able to avoid, much less prevent, the Mafialike scene which was played out in front of me, as it had been so many times before. Being beaten with a belt buckle naturally made the "thin-skinned" doctor writhe in agony. And when the blows began to fall incessantly, $x$ screamed, begging for mercy. As I watched, I suddenly felt like vomiting. Not because I felt sorry for him, and not, in case you may think it, because I was opposed to what was happening. It was just that I wasn't used to watching people being tortured. As usually happened when I watched someone being tortured, the torture of $X$ made me tremble. I trembled violently. Trembled as though I had an attack of malaria.

The unpleasantness of the whole thing gripped me. Seeing these acts, which brought to life my picture of "Smersh" techniques, made my stomach trouble come back. I had to get away. I pretended I wanted to urinate. In the bathroom, I vomited again and again. I was dreadfully afraid that Doctor $X$ would have to be "sacrificed" if he held to his position.

When I came out of the bathroom, $X$ wasn't in my office any more. I asked the Commandant, who accidently bumped into me in the corridor, about him. He said that $X$ had been "secured" in a "safer place." This was the first time I had heard that term, and to this very day $I$ don't understand it.

5.

It was bitter experiences like these that drove me to ask for a transfer to another position on the Interrogating Team. My request was granted, and I was even given the position I wanted. I moved out to the back, to the section of "Prisoner Supervision." It looked like the nicest kind of work.

But even here I had to swallow bitter pills, though in a different form. Once again, I had to rend my inner spirit (to put it grandiosely). It began like this. 
Because Sukarno praised the Gerwani, ${ }^{4}$ anger flared up among certain groups of the armed forces. When he said that the Gerwani was "good and hadn't done anything at all," he was wrong. When he claimed that the "Gerwani was innocent," he was stupid. Some men in the military, who were quite convinced that the Gerwani had been at Lubang Buaja, were naturally outraged when they heard the Sukarno speech, relayed over Radio Republic Indonesia, in which he said in effect that none of the Gerwani had been involved at Lubang Buaja. The theme of Sukanno's speech at the Mothers' Day celebrations in Djakarta at the end of 1965 became a casus belzi. And that was why Sri and Ibu $Y$ had to be executed. It was as if Sri had been born to be the victim of sukarno's demagogy. An ill-starred life.

6 .

Sri was a classmate of mine; it seems she was an activist in the CGMI. ${ }^{15}$ I swear I never suspected it, maybe because outside organizations were not permitted at school, or maybe because I didn't associate much with Sri. I think it's going too far to say that a girl of 24 was a ring-leader of the CGMI. I knew no more about Sri than that she was a wayang dancer, and that she took the role of Arimbi. But when I read the material about her in the files of the Interrogating Team, I was really shocked. Sri was listed as a "participant" at Lubang Buaja! To me this was rather incredible, since in the days just prior to the coup I had met her myself. In fact, at the Dies Natalis held about nine or ten days after september 30, 1965, I saw Sri again, with her boyfriend. But all this is really beside the point. The point is that sri in the end "had" to die.

At first Sri was thrown into Camp II, which subsequently had come under my charge. I met Sri there, and the day before it happened, I had a chance to talk to her behind the bamboo gates of the camp. She cried and begged me to tell her boyfriend in Mertodranan about her "fate." I said "yes," although this was a lie. Sri's boyfriend was actually no longer in Mertodranan. He had been arrested too, and, in fact, Sri wasn't very far away from him. Sri and $M$, her boyfriend, were deliberately kept in the dark, especially since both of them were in a "serious" situation. But so as not to discourage her, that evening I tried to calm her by saying that $I$ had met $M$ and that he was quite well: "Quite well" is news generally well received, but on this occasion, it made Sri suspicious. "Quite well?"

Sri asked in astonishment. "Oh yes," I answered. "Thank God!" she said, moving away from the gate because a guard was watching

14. Gerwani, Gerakan Wanita Indonesia, the communist women's organization.

15. CGMI, Concentrasi Gerakan Mahasiswa Indonesia, a communistdominated student movement. 
us from some distance away. From the look in her eyes, I could see that Sri didn't believe me; and I even regretted speaking, for I didn't know whether Sri had become calmer or more upset from the news.

The next day, I was on guard duty. That night Djakarta Radio, relayed by Solo Radio, broadcast a repeat of the speech. Once more, we were made aware of Sukarno's attitude, for he spoke without heed for the conditions which existed in our society at that time. Perhaps he had forgotten that an unofficial state of war already existed in solo.

To this very day, I can still remember how the soldiers who had supposedly seen the Generals' corpses in Lubang Buaja reacted to that speech of "praise" for the Gerwani. Some of them drove to the town hall in a truck. They came in, taking turns at firing off their guns while shouting cynically, "Long live the Gerwani and Bung Karno! Long live the Gerwani and Bung Karno!"

I was sitting in the guardhouse at the time. I was startled to hear the shooting and Communist-sounding yells. I was still more startled when they all crowded into the guardhouse and shouted, "Good evening." When I saw who they really were, little by little my anxiety lessened.

What they wanted was quite routine: the list of the names and records of the prisoners. Twice before I had been faced with such a request, and this time too I handed over the list. Together they picked out names, mostly those of prisoners in Groups A and B. But what did I discover later? Sri had been "chosen." As usual, I had to go straight to Camp I and Camp II to summon them. Although the shots had only been fired into the air, it had made some of the prisoners weak with fear. The shooting convinced me all the more that we were really and truly in a state of war.

Some of the soldiers followed me to the back. My task was only to call out the names which had been marked, like a teacher taking the class roll and it really wasn't so hard to call out the names of people whom I didn't know, or who didn't know me. But in Camp II, where I had to call out the names of Sri and Ibu $Y$, I was gripped by extraordinary panic. It crossed my mind to fool the soldiers by pointing out other women. But I was afraid. They checked the names by questioning each person I had summoned individually. Eventually, with forced courage, I called Sri and Ibu Y, whose names I had left until the very end.

Ibu $Y$ went past me, silent and bowed. But Sri, who only the day before had chatted with me as a close friend, rebuked me. She said in a low, half-trembling voice: 
"How do you have the heart to do this, Us, when it's not
even clear I've done anything wrong?"

My whole body felt weak. That voice, yes, that voice tied my heart in knots. I was sure Sri knew where she was to be taken. I didn't answer, and maybe that seemed even more cruel to Sri. It was lucky that the soldiers who led them away didn't hear anything. What should I have said to Sri? I had no opportunity to speak. I didn't have a chance to explain to her that I was only on duty at the guardhouse, under orders and forced to carry them out. Sri certainly must have been full of hate and bitterness as she approached her death. I wanted to cry out and tell her that I had honestly meant to substitute another name for hers--for example, that of Kijem, a Gerwani prostitute. But they were so very thorough. And I was terrified. I was really terrified to be thought in league with Sri. Perhaps I did cry out, but it was only I myself that heard the cry. I couldn't bear it any longer. I didn't have the nerve to point out my own friends for execution.

I also had to accept the invitation of my "friends" who were going to execute the fourteen prisoners. This too was a fait accompli. Squeezed in between the soldiers who drove the truck carrying the fourteen prospective corpses, I came to Modjo, a village on the west side of Solo. We stopped there for awhile. A few of the men, drunk, were still shouting abuse at the Gerwani and mimicking sukarno-style speeches. I really did understand their anger; they really felt that their grief had been mocked. I understood that such things must happen in war, and it seemed very natural that in such chaotic conditions, morality will be put aside. Their yells became more hysterical, echoing into every corner of Modjo, as the fourteen prisoners moved with dragging steps to the river's edge.

Sri started to cry when she was taken down out of the truck. Ibu Y, the teacher, was tense but calm. She didn't cry. Her expression was bitter as gall.

When they reached the steep river bank, they were lined up in rows. I can still hear the chorus of moans. I can still hear the series of heavy objects falling into the water. After that, I heard nothing more. All I remember was the world spinning in front of my eyes. In a way it felt like falling asleep but it was more like being dizzy. I fell asleep, or blacked out, God only knows.

At one o'clock I was brought back to the post and reported the incident from the telephone there. The Commandant was evidently quite used to getting this kind of report. He said:

"All right, just make out a written report."

I had reached the peak of horror in my work there; I just couldn't bear it any longer. Although this sort of thing was 
normal on the battlefield, and although the same things that were done to Sri might have been done to me if the PKI had won, my soul, my heart, was not tough enough to face realities and necessities like these. I don't blame anyone. No one was guilty. Even in writing about it, I have altered the names, keeping the real ones secret so that these are nothing more than personal notes. Without such people as the former Commandant of my Team, without resolute soldiers like those who gave active "lessons" to the Communists in Solo, "lessons" such as were given to Sri, Ibu $Y$ and Doctor X, perhaps the crushing of G-30-S would still not be over. Indeed, Central Java in general and Solo in particular might have become like Da Nang, a battlefield in Vietnam. If all the officials had been like me, maybe the whole situation would have been reversed. It could even have been the other side which held the initiative. So I decided to leave the Team. More than that, I felt I had to leave Solo.

I just wasn't able to draw up a report "condemning" Sri or Ibu $Y$ and I could not describe objectively how Sri had been dragged to the Camp and how she had been "executed" before ever being "interrogated."

I went through five hours of great tension the last day there, when I was supposed to be making out the report listing the reasons for the "final solution" for Sri and the others. That day I planned to "run away" from my duties without taking leave of the commandant. And eventually I did just that. There never was a report from me about Sri. I also avoided meeting the Commandant of the Team.

It was only to my aunt that I told my plan to go back to Pekalongan. I left solo on the night bus, a person who had turned around and abandoned his responsibilities. To hell with anything I might be accused of. I was fed up and couldn't go on with the hypocrisy any longer.

I left Solo. None of my friends knew, and none of my colleagues on the Team. Running away? Yes, running away! I knew perfectly well talk would go around about my cowardice. Without reason or basis, much less any background knowledge. But I didn't care about any of that. I had to rest in order to calm my shattered nerves. One could also say it was perhaps a protest against Sri's "misconceptions." I wanted to think that Sri had died without any "misconceptions" about me. Let alone hatred. But the chances were very slight. Thus the only way out was to get rid of the melancholy that came over me as a result of what had happened to Sri. God knows, I couldn't bear to watch it. 